\title{
Opened Problems Of The Application Of IAS 39 On Reporting Of Financial Derivatives In The Czech Republic
}

Jiří Strouhal, (E-mail: strouhal@vse.cz), University of Economics in Prague, Czech Republic

\begin{abstract}
Although in the United States derivatives have been traded since around the middle of the nineteenth century, in the Czech Republic a derivative was an unknown term until lately - or rather a term referring to someplace in an ununknown empire. The situation started to change roughly in the second half of nineties, when as part of macroeconomic shocks and government crisis in 1997 when interest rates increased significantly and the Czech crown devaluated from day to day. At that time, companies felt, for the first time ever, how heavy impact an unexpected and not counted on change of market conditions may have on them. From 2001 to 2004, another unusual phenomenon occurred which shook the business sector; should a prophet predicted it at the end of the nineties, he would probably be clamed to be crazy. The exchange rate of dollar against crown dropped from over 40 CZK/USD to 20 CZK/USD. Companies that made contracts with their customers in dollars but with suppliers in crowns bore a great exchange rate risk and they frequently paid a lot when dollar dropped. At the moment we also have to mention world prices of oil and oil products which rocketed so high that nobody could have expected it several years ago.
\end{abstract}

This paper focuses on the comparison of reporting of the derivatives using IFRS in comparison with the Czech accounting legislature by the companies listed on the Prague Stock Exchange (PSE). Study draws the attention to check the differences in reporting of derivatives and also compares their qualitative advantages. Results of this study are based on the analysis of annual reports of the companies listed on the PSE. Any of analyzed companies didn't allow all of the requirements of IFRS on reporting of the financial derivatives.

\section{INTRODUCTION}

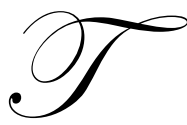

he motives why Czech companies started or are starting to make derivative businesses are a few. The praiseworthy motive is the control of financial risk, elimination of possible unexpected losses from unpredictable movement of exchange rates, interest rates, commodity prices or other market factors which a company cannot affect in any way. This motive, however, is not the only one. In lots of cases companies conclude derivate trades - although they hardly admit it - simple because they want to try such a business. And there are also businesses - fortunately only exceptional - when a company agrees derivates that even cannot be determined as hedging and they represent only mere speculation, or an adrenaline game in the market casino. We should also add that such an adrenaline game usually is hidden under the robe of complex models and studies, adding the special tinge of scientific, modern and progressive qualities.

In the Czech business sector derivates are admissible mainly via banks. The access to derivative stock exchange is rather complicated and is related with considerable transaction costs. Some companies, however, are offering the access to derivative stock exchange and it will only take some time before Czech companies start up search for the access actively. 


\section{MAIN TARGETS}

This paper focuses on the comparison of reporting of the financial derivatives using IFRS in comparison with the Czech accounting legislature by the companies listed on the Prague Stock Exchange. Results of this study are based on the analysis of annual reports of 51 companies listed on the Prague Stock Exchange. Currently there are traded 133 securities on the Prague Stock Exchange:

Table 1: Securities Listed on the Prague Stock Exchange

\begin{tabular}{|l|c|c|c|}
\hline & Stocks & Bonds & Total \\
\hline Primary Market & 8 & 25 & 33 \\
\hline Secondary Market & 25 & 17 & 42 \\
\hline Free Market & 14 & 44 & 58 \\
\hline Total & 47 & 86 & 133 \\
\hline
\end{tabular}

The most important players on the Prague Stock Exchange are definitely the financial institutions and majority of bonds are state bonds. We focus our analysis on corporations listed on the PSE. We will analyze 51 companies (see the following table):

Table 2: Segmentation of Analyzed Companies

\begin{tabular}{|l|c|}
\hline Segment of the Industry & Analyzed Companies \\
\hline Traffic, Communications & 3 \\
\hline Timber and Paper Industry & 1 \\
\hline Energetic & 20 \\
\hline Chemical Industry, Pharmaceuticals & 5 \\
\hline Trade & 3 \\
\hline Services & 6 \\
\hline Construction Industry & 2 \\
\hline Mechanical Engineering & 3 \\
\hline Textile and Clothing Industry, Leather Manufacture & 1 \\
\hline Mining & 3 \\
\hline Food Industry & 4 \\
\hline Total & 51 \\
\hline
\end{tabular}

\section{ANALYSIS ASSUMPTIONS}

Defined targets of our analysis focus on empirical data including their impact on the financial results of analyzed companies. The main problem is getting the sensitive information needed from the management of the companies. We will focus our analysis on the data published in the Annual Reports of the companies and their Financial Statements for the period of 2004. All data presented is measured in thousands CZK.

\section{Derivative OPERATions OF THE CZECH COMPANIES}

\section{Traffic and Communications Industry}

In the industry of traffic and communications, the main player is definitely the Český Telecom, the main phone operator in the CR. It is the only company in this industry using derivatives. The main characteristic of the telecommunication companies is their geographic expansion which is linked with the impact of the changing currency exchange rates as well as the changing interest rates. Usually the companies don't use the commodity derivatives. 
Český Telecom implemented centralised risk management of the parent company (Telefónica O2) and also implemented the hedge accounting. The fair value of the derivatives operation of the company is loss. Impact of the using the derivatives instrument on the Balance Sheet is absolutely insignificant.

\section{Mechanical Engineering}

In the engineering industry, the main Czech player is Škoda Auto, a member of the Volkswagen Group. As well as in the Český Telecom also Škoda Auto implemented Volkswagen's system of the risk management and therefore the impact of the derivative operations on the financial results of the company are alike Volkswagen. Fair value of the derivative operations was significantly positive. Opposite to other companies Group presents many details about their risk management and about the derivative operations. One quarter of the hedging operations was noneffective. Impact of the effective part of the derivatives on the balance sheet was however less than $1 \%$.

\section{Energetic Industry}

For the companies of the energy industry, the tendency is to speculate on the price of the oil. Paradox the Czech companies are the exemption of this trend and they don't use derivatives for the speculation.

The main players of this industry are the power-station giant ČEZ and the gas holding RWE. Companies from the holding RWE don't use derivative operations anymore. The ČEZ Group is the leader of the Czech stock market. However the information given in the Annual Reports about the risk management and their derivative operations are very incomplete. There are given only the aggregate sums for the fair values of the derivatives used for the fair value hedge and the cash flow hedge. The Group is unable to give the information about the types of the derivatives it uses (all derivatives of this Group are published in the item "other (non specified)"). ČEZ have many loss derivatives, but their impact on the balance sheet is less than $2 \%$.

\section{Chemical Industry and Pharmaceuticals}

Unipetrol Group is the leading company of the Czech chemical industry. The Group doesn't use the derivative operations for the speculation but only for the economic hedging of their risks. The risk management of the Group is decentralized. From the Financial Statements of the Group we can see tiny impact of the derivative operations on the financial results of the Group, but the fair value of the derivative operations was negative.

Very important company of the pharmaceutical industry is the Czech leader Zentiva. This company is the very successful player of the Prague Stock Exchange. Zentiva uses derivative operations very temperately. Surprisingly the company decided to not use the hedge accounting. Zentiva uses the derivative operations for managing the currency risks and all their operation are reported as derivatives for trading. The risk management of the company is centralized. The fair value of the derivative operations in 2002 and 2003 was negative and the using of these operations in Zentiva went down. As at 31 December 2004 the company didn't have any derivative operation. Impact of these operations on the balance sheet is therefore null.

\section{Other Industries}

Quite interesting is using of the FX option by the spa company Lázně Teplice v Čechách. This option was reported as a derivative operation held for trading. The fair value of this option was expressively positive, but the impact on the financial results of the company was only about $2 \%$.

The traditional player of the Prague Stock Exchange is the leader of the tobacco industry Philip Morris ČR. Company operated with the FX option, but this derivative operation had positive fair value with the null impact on the balance sheet. 
There are industries with no using of the derivatives operations, such as trade, timber and paper industry and the construction industry. The Czech leader of the textile industry Slezan Frýdek-Místek uses the FX forwards, but their impact on the financial results was null.

\section{CONCLUSION}

The main conclusion of this analysis is the fact, that the impact of using derivative operations on the financial results of the companies is very low. If the company has the positive or negative result of these operations, their impact on the balance sheet was less than $2 \%$.

As for the derivative typology, the companies in Czech prefer in the management of currency risks the FX forwards much more than FX options. In the way of interest rate derivatives, companies prefer interest rate swaps. The quite surprising fact of our analysis is that the Czech companies listed in Prague Stock Exchange don't use commodity derivatives.

Figure 1: Derivatives and Their Impact on the Financial Results

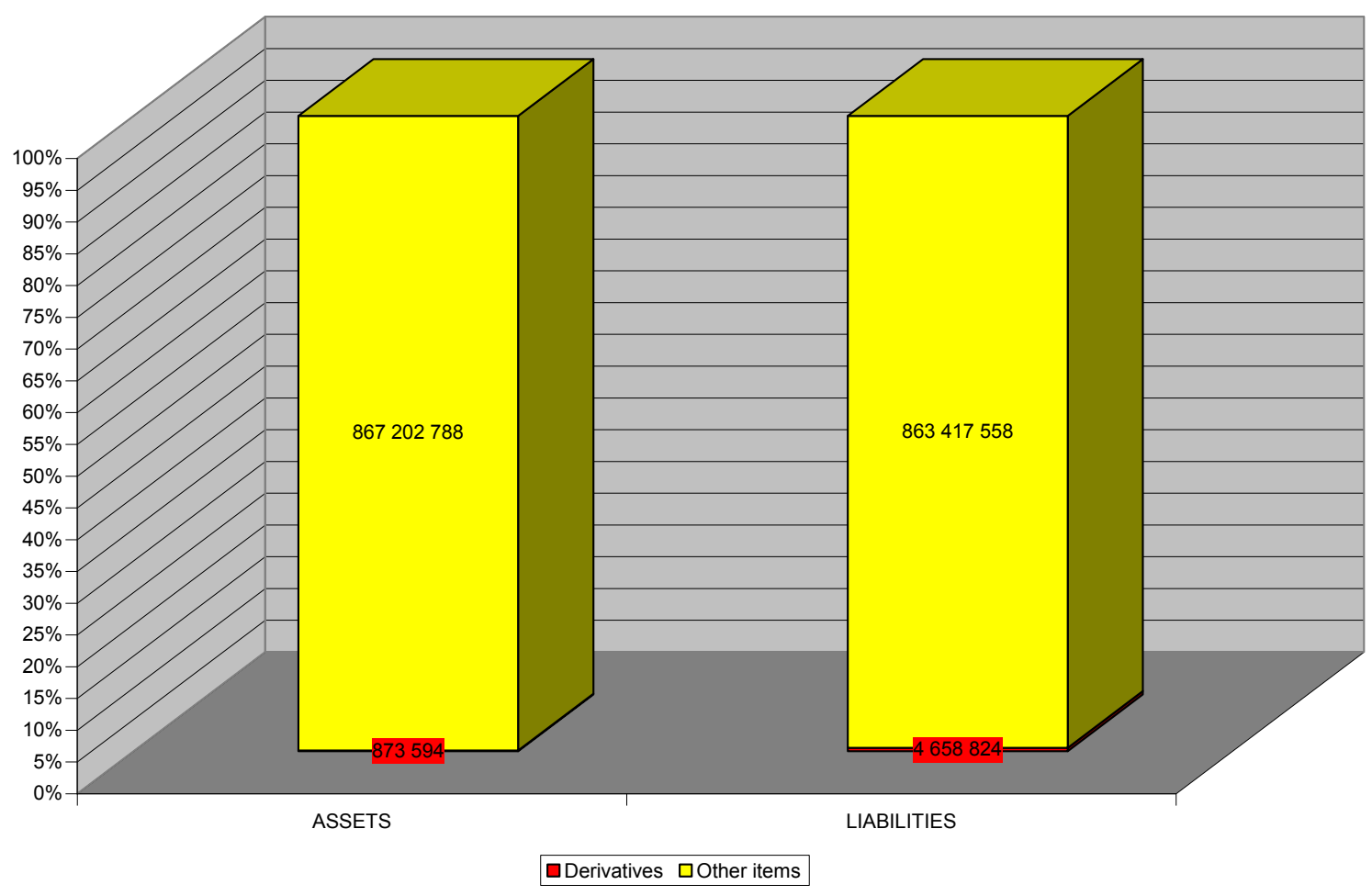


Figure 2: Derivatives as A Part of Assets

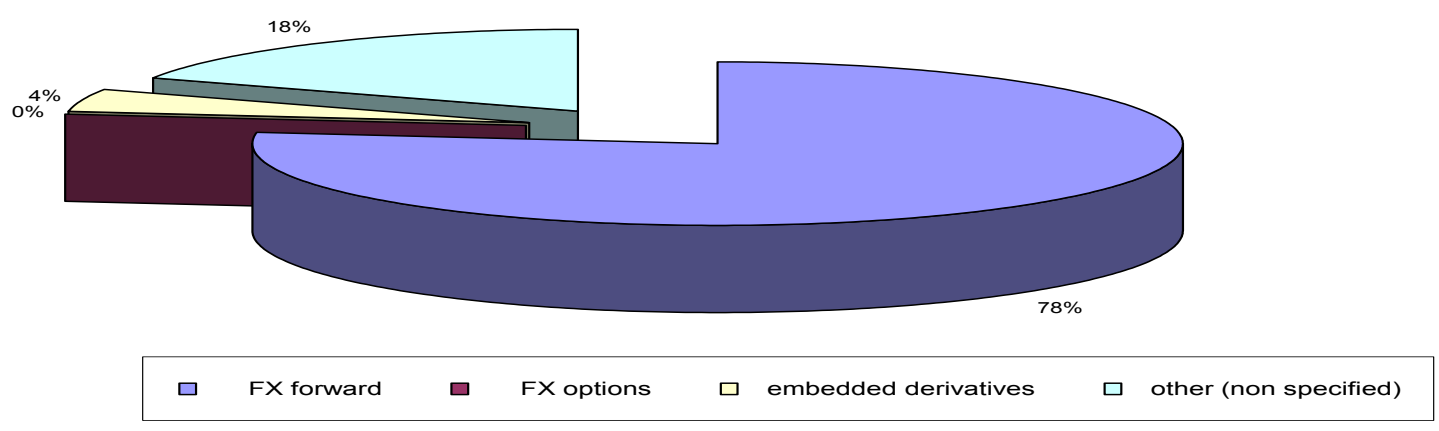

Figure 3: Derivatives as A Part of Liabilities

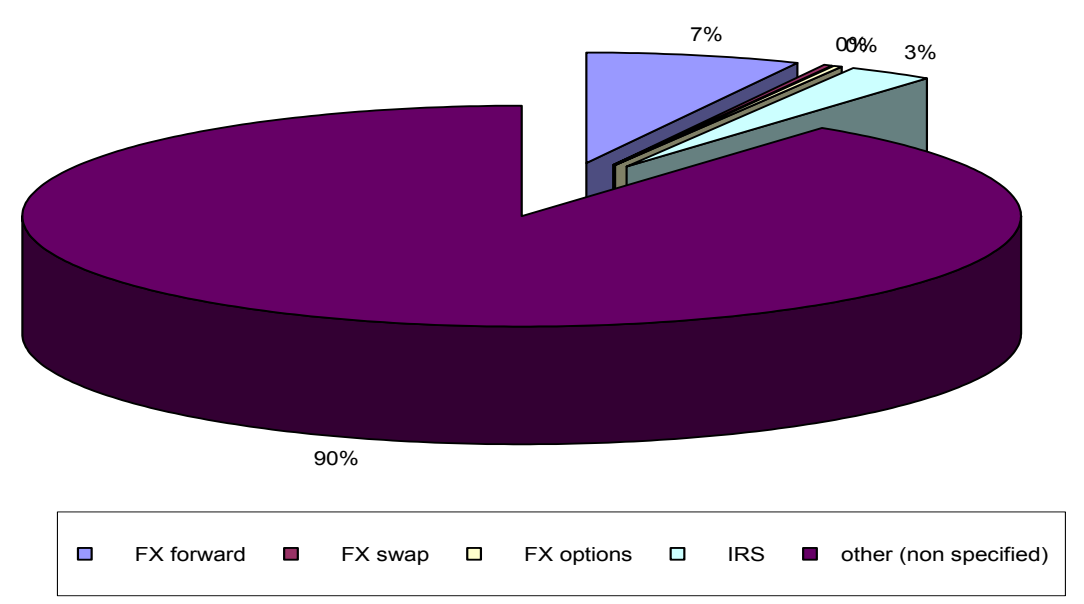




\section{OPENED PROBLEMS OF REPORTING OF THE DERIVATIVES}

The main problem of the reporting about the derivative operations is the very low level of the information about derivatives. Moreover the companies are in this way non-uniform although they should meet the requirements of IAS 32 and IAS 39. Therefore the data are very difficult to compare and interpret.

Information about the structure of the derivative operations, their nominal and fair values, types of the derivative instruments are crumbled on whole length of the annual report. For example company reports the nominal values for each type of the derivative instrument, but the fair value of these instruments is aggregated only for the types of the financial risks. Other problem is the reporting of cross currency swaps. Some companies reports CCS as a part of the currency risks, other companies as a art of the interest rate risks.

Majority of the companies didn't report the information about their hedging strategies. The shareholders of these companies therefore have no information about the fact which part of the sum could be classified as a fair value hedge and which part as a cash flow hedge. There were reported no information about the measurement of the efficiency of the hedge accounting. Companies only cribbed the Act about derivatives.

\section{CONCLUSION}

Information given in the companies' annual reports is formal, non-uniform and without any polished system. Majority of the companies reported, that the derivative operations are not used for speculation. Therefore the companies which didn't mention this fact demonstrably use derivative operations for the speculation. We assume that the companies are nowadays more cautious in using these operations than in previous years. But we should realize that the very low level of the information about the derivative operations have the negative impact on the possibility of making fair financial decisions because of the information asymmetry. Another problem is the measurement of the fair value in the Czech OTC derivative market.

\section{REFERENCES}

1. GRIFFITHS, A., GANDY, B., and MANN, W., Adjusting for Fair Value of Debt and Related Derivatives in Corporate Analysis, www.fitchratings.com, 2006, 6 pages.

2. Gandy, B., MerRitT, R., Oline, M., and MAnN, W., Hedge Accounting and Derivative Study for Corporates, www.fitchratings.com, 2004, 13 pages.

3. Strouhal, J., Accounting of Financial Derivatives, CP Books, Brno 2005, ISBN: 80-251-0754-X, 117 pages.

4. Strouhal, J., Financial and Accounting Aspects of Financial Options, Dissertation Work, University of Economics, Prague 2005, 178 pages.

5. www.fitchratings.com (Fitch Ratings).

6. www.iasb.org (International Accounting Standards Board).

7. www.iasplus.com (IFRS/IAS).

8. $\quad$ www.pse.cz (Prague's Stock Exchange).

9. Annual Reports of the companies listed on Prague's Stock Exchange. 


\section{APPENDICES}

Table 3: Traffic and Communications Industry

\begin{tabular}{|c|c|c|}
\hline & ATIONS & $\begin{array}{l}\text { Impact on the } \\
\text { Balance Sheet }\end{array}$ \\
\hline ASSETS & 239926171 & $100,00 \%$ \\
\hline Derivatives (receivables) & 15 & $0,00 \%$ \\
\hline currency derivatives & 15 & $0,00 \%$ \\
\hline FX forward & $O$ & $0,00 \%$ \\
\hline FX swap & 0 & $0,00 \%$ \\
\hline FXoptions & 15 & $0,00 \%$ \\
\hline interest rate derivatives & 0 & $0,00 \%$ \\
\hline FRA & $O$ & $0,00 \%$ \\
\hline IRS & $O$ & $0,00 \%$ \\
\hline IRO & $O$ & $0,00 \%$ \\
\hline commodity derivatives & 0 & $0,00 \%$ \\
\hline embedded derivatives & 0 & $0,00 \%$ \\
\hline other (non specified) & 0 & $0,00 \%$ \\
\hline Derivatives (payables) & 162485 & $0,07 \%$ \\
\hline currency derivatives & 151295 & $0,06 \%$ \\
\hline FX forward & 143620 & $0,06 \%$ \\
\hline FX swap & $O$ & $0,00 \%$ \\
\hline FX options & 7675 & $0,00 \%$ \\
\hline interest rate derivatives & 11190 & $0,00 \%$ \\
\hline FRA & $O$ & $0,00 \%$ \\
\hline IRS & 11190 & $0,00 \%$ \\
\hline IRO & $O$ & $0,00 \%$ \\
\hline commodity derivatives & 0 & $0,00 \%$ \\
\hline embedded derivatives & 0 & $0,00 \%$ \\
\hline other (non specified) & 0 & $0,00 \%$ \\
\hline
\end{tabular}

Table 4: Mechanical Engineering

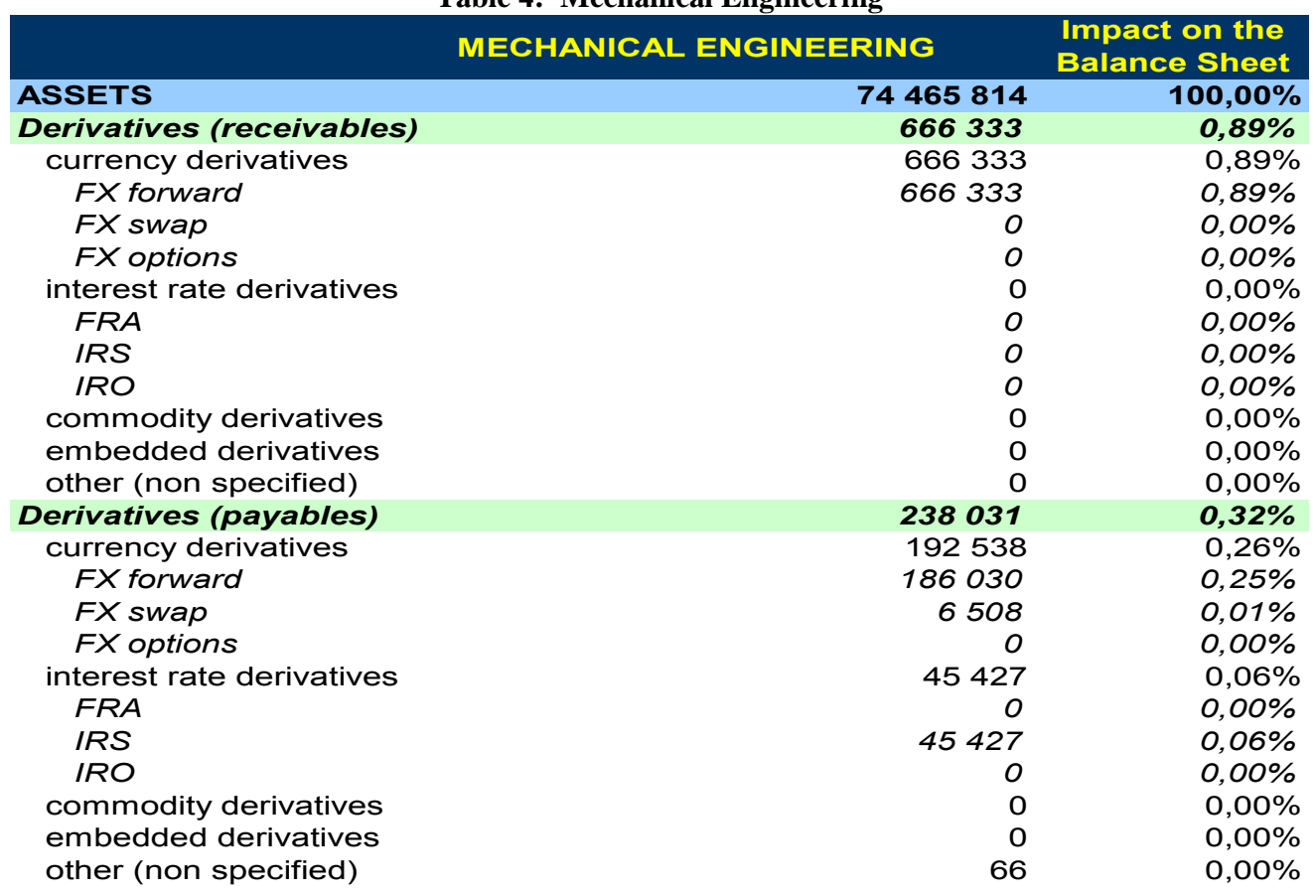


Table 5: Energetic Industry

\begin{tabular}{|c|c|c|}
\hline \multicolumn{2}{|c|}{ ENERGETIC } & $\begin{array}{l}\text { Impact on the } \\
\text { Balance Sheet }\end{array}$ \\
\hline ASSETS & 339736676 & $100,00 \%$ \\
\hline Derivatives (receivables) & 159335 & $0,05 \%$ \\
\hline currency derivatives & 0 & $0,00 \%$ \\
\hline$F X$ forward & $O$ & $0,00 \%$ \\
\hline FX swap & $O$ & $0,00 \%$ \\
\hline FX options & $O$ & $0,00 \%$ \\
\hline interest rate derivatives & 0 & $0,00 \%$ \\
\hline FRA & $O$ & $0,00 \%$ \\
\hline IRS & $O$ & $0,00 \%$ \\
\hline $\operatorname{IRO}$ & $O$ & $0,00 \%$ \\
\hline commodity derivatives & 0 & $0,00 \%$ \\
\hline embedded derivatives & 0 & $0,00 \%$ \\
\hline other (non specified) & 159335 & $0,05 \%$ \\
\hline Derivatives (payables) & 4200138 & $1,24 \%$ \\
\hline currency derivatives & 0 & $0,00 \%$ \\
\hline$F X$ forward & $O$ & $0,00 \%$ \\
\hline FX swap & $O$ & $0,00 \%$ \\
\hline FX options & $O$ & $0,00 \%$ \\
\hline interest rate derivatives & 25365 & $0,01 \%$ \\
\hline$F R A$ & $O$ & $0,00 \%$ \\
\hline IRS & 25365 & $0,01 \%$ \\
\hline $\operatorname{IRO}$ & $O$ & $0,00 \%$ \\
\hline commodity derivatives & 0 & $0,00 \%$ \\
\hline embedded derivatives & 0 & $0,00 \%$ \\
\hline other (non specified) & 4174773 & $1,23 \%$ \\
\hline
\end{tabular}

Table 6: Chemical Industry and Pharmaceuticals

\begin{tabular}{|c|c|c|}
\hline & $\begin{array}{l}\text { CHEMICAL INDUSTRY, } \\
\text { PHARMACEUTICALS }\end{array}$ & $\begin{array}{l}\text { Impact on the } \\
\text { Balance Sheet }\end{array}$ \\
\hline ASSETS & 91727434 & $100,00 \%$ \\
\hline Derivatives (receivables) & 0 & $0,00 \%$ \\
\hline currency derivatives & 0 & $0,00 \%$ \\
\hline FX forward & $O$ & $0,00 \%$ \\
\hline FX swap & $O$ & $0,00 \%$ \\
\hline FX options & $O$ & $0,00 \%$ \\
\hline interest rate derivatives & 0 & $0,00 \%$ \\
\hline FRA & $O$ & $0,00 \%$ \\
\hline IRS & $O$ & $0,00 \%$ \\
\hline IRO & $O$ & $0,00 \%$ \\
\hline commodity derivatives & 0 & $0,00 \%$ \\
\hline embedded derivatives & 0 & $0,00 \%$ \\
\hline other (non specified) & 0 & $0,00 \%$ \\
\hline Derivatives (payables) & 58069 & $0,06 \%$ \\
\hline currency derivatives & 0 & $0,00 \%$ \\
\hline FX forward & $O$ & $0,00 \%$ \\
\hline FX swap & $O$ & $0,00 \%$ \\
\hline FXoptions & $O$ & $0,00 \%$ \\
\hline interest rate derivatives & 58069 & $0,06 \%$ \\
\hline$F R A$ & $O$ & $0,00 \%$ \\
\hline IRS & 58069 & $0,06 \%$ \\
\hline $\operatorname{IRO}$ & $O$ & $0,00 \%$ \\
\hline commodity derivatives & 0 & $0,00 \%$ \\
\hline embedded derivatives & 0 & $0,00 \%$ \\
\hline other (non specified) & 0 & $0,00 \%$ \\
\hline
\end{tabular}


Table 7: Derivatives and Their Impact on the Financial Results

$\begin{array}{lrr} & \text { SUMMARY } & \begin{array}{c}\text { Impact on the } \\ \text { Balance Sheet }\end{array} \\ \text { ASSETS } & \mathbf{1 0 0 , 0 0 \%} \\ \text { Derivatives (receivables) } & \mathbf{0 7 6 3 8 2} & \mathbf{1 0 0 , 1 0 \%} \\ \text { currency derivatives } & \mathbf{8 7 3 4} & 0,08 \% \\ \text { FX forward } & 675099 & 0,08 \% \\ \text { FX swap } & 66633 & 0,00 \% \\ \text { FX options } & 0 & 0,00 \% \\ \text { interest rate derivatives } & 804 & 0,00 \% \\ \text { FRA } & 0 & 0,00 \% \\ \text { IRS } & 0 & 0,00 \% \\ \text { IRO } & 0 & 0,00 \% \\ \text { commodity derivatives } & 0 & 0,00 \% \\ \text { embedded derivatives } & 0 & 0,00 \% \\ \text { other (non specified) } & 39160 & 0,02 \% \\ \text { Derivatives (payables) } & 159335 & \mathbf{0 , 5 4 \%} \\ \text { currency derivatives } & \mathbf{6 5 8} \mathbf{8 2 4} & 0,04 \% \\ \text { FX forward } & 343934 & 0,04 \% \\ \text { FX swap } & 329751 & 0,00 \% \\ \text { FX options } & 6508 & 0,00 \% \\ \text { interest rate derivatives } & 7675 & 0,02 \% \\ \text { FRA } & 140051 & 0,00 \% \\ \text { IRS } & 0 & 0,02 \% \\ \text { IRO } & 140051 & 0,00 \% \\ \text { commodity derivatives } & 0 & 0,00 \% \\ \text { embedded derivatives } & 0 & 0,00 \% \\ \text { other (non specified) } & 0,48 \%\end{array}$


International Business \& Economics Research Journal - February 2007

Volume 6, Number 2

NOTES 